DOI: $10.19195 / 2084-5065.43 .4$

\title{
Uwagi o zasadach wymiaru kary w polskich kodeksach karnych
}

\author{
TADEUSZ BOJARSKI \\ Katedra Prawa \\ Uniwersytet Technologiczno-Humanistyczny w Radomiu \\ Uniwersytet Marii Curie-Skłodowskiej w Lublinie
}

Zasady wymiaru kary stanowią zespół ważnych reguł przy stosowaniu kary kryminalnej. Oprócz istotnego znaczenia praktycznego, co oczywiste, są ściśle związane z zagadnieniami teorii i filozofii kary. Zazwyczaj założenia w kwestii wymiaru kary łączą się z określoną koncepcją (teorią) kary. W związku z tym, oprócz ich wysokiego znaczenia praktycznego, ujawnia się tutaj również ważny aspekt teoretyczny — bogaty i wielokierunkowy. Nawiązują one do ogólnej teorii kary (teorie bezwzględne, względne, mieszane), łącząc niejednokrotnie różne elementy z kręgu tych teorii. Teorie kary wskazują na określone cele kary, można je rozpatrywać także w kontekście szerszym - celów prawa w ogóle. W ujęciu historycznym wskazuje się m.in. na cel ochrony dobra ogólnego, ochrony bezpieczeństwa jednostki, cel sprawiedliwościowy ${ }^{1}$. Nie rozważamy w tym miejscu tych zagadnień bliżej jako problemu szerszego, wielokrotnie rozpatrywanego w polskiej literaturze prawa karnego dawniejszej i współczesnej ${ }^{2}$. Celem przedstawio-

1 Zob. W. Makowski, My i wy, Warszawa 1938, s. 141. O współczesnym znaczeniu pojęcia „wymiar sprawiedliwości” i samej kwestii sprawiedliwości, także w kontekście konstytucyjnym i procesowym, zob. bliżej J. Skorupka, O wymiarze sprawiedliwości, jej wymierzaniu w sprawach karnych oraz o instytucjach to gwarantujacych, [w:] Na styku prawa karnego i prawa o wykroczeniach. Ksiega Jubileuszowa dedykowana Profesorowi Markowi Bojarskiemu, red. J. Sawicki, K. Łucarz, Wrocław 2016, s. 467 n.; z pozycji dawniejszych zob. w tej kwestii S. Glaser, Pojęcie sprawiedliwości w prawie karnym, Wilno 1925.

2 Zob. E. Krzymuski, System prawa karnego, wyd. III, t. I. Podstawy filozoficzne prawa karnego (teorie karne), Kraków 1911, s. 16 n., s. 50 n.; S. Glaser, Polskie prawo karne w zarysie, Kraków 1933, cz. V. Kary i środki zabezpieczajace. Środki wychowawcze i poprawcze, paragraf 4, s. 246 n.; J. Makarewicz, Prawo karne. Wykład porównawczy, Lwów-Warszawa 1924, s. 24 n.; W. Wolter, Zarys systemu prawa karnego. Część ogólna, t. II, Kraków 1934, księga III. Kara od- 
nych uwag jest proste wskazanie na założenia dotyczące zasad wymiaru kary, na których się one opierają, z uwzględnieniem drogi rozwojowej polskiego prawa karnego od 1932 r. Wybór tematu jest uzasadniony znaczeniem, prawdziwym bogactwem problemów, jakie się tu pojawiają, w tym w warstwie teoretycznej, lecz także zainteresowaniami badawczymi Jubilata, Profesora Tomasza Kaczmarka, jak również wrocławskiego zespołu naukowego w całości, poczynając od profesora W. Świdy³.

Kodeks karny z 1932 r., oparty na założeniach szkoły socjologicznej, zawierał w art. 54-58 podstawowe wskazówki, ważne przy wymiarze kary. Nie określał słownie poszczególnych zasad, lecz jego postanowienia zawierały odpowiednie wskazania dla sędziego, który powinien nimi się kierować przy orzekaniu kary sprawcy przestępstwa. Tytuł rozdziału był ujęty ogólnie — „Wymiar kary”. Z postanowień kodeksowych wynikają: 1) zasada swobodnego sędziowskiego uznania, 2) zasada indywidualizacji kary, 3) zasada zależności kary grzywny od stosunków majątkowych sprawcy, 4) zasada preferencji kary wolnościowej, 5) zasada zaliczania tymczasowego aresztowania na poczet orzekanej kary pozbawienia wolności. Nadto, obok wymienionych założeń ogólnych, art. 54 wskazywał na przesłanki szczególne (okoliczności) wymiaru kary szeroko ujętej ${ }^{4}$ Można tu pominąć reguły związane z nadzwyczajnym złagodzeniem kary i wymiarem kary sprawcy powrotnemu (art. 59-60 k.k.) jako problemy szczególne, chociaż związane z ogólnymi zasadami wymiaru kary. Zagadnienia nadzwyczajnego wymiaru kary stanowią jednak temat odrębny 5 . Kodeks karny z 1932 r. wysuwał na czoło zasadę swobodnego uznania sędziowskiego i to założenie zostało przyjęte również w rozwiązaniach kodeksów następnych. Zasada sędziowskiej swobody przy orzekaniu

wetowa i kara celowa, s. 12 n., s. 24-26; zob. też J. Utrat-Milecki, Kara. Teoria i kultura penalna: Perspektywa integralnokulturowa, Warszawa 2010, w szczególności rozdział I Racjonalizacje kary, s. 41 n.; J. Warylewski, Kara. Podstawy filozoficzne i historyczne, cz. I. Podstawy filozoficzne, Gdańsk 2007, s. 11 n.; W. Dadak, Od klasycyzmu do populizmu czyli o funkcjach kary kryminalnej w społeczeństwie, [w:] Od szkoły klasycznej do neoklasycznej w prawie karnym, red. J. Widacki, Kraków 2016, s. 165 n.; O prawo karne oparte na zasadach sprawiedliwości, prawach człowieka i miłosierdziu, red. A. Strzębosz, Lublin 1988; z pozycji dawniejszych zob. Z. Papierkowski, Socjologiczne i filozoficzne oblicze kary, Lublin 1947.

3 T. Kaczmarek, zob. w szczególności prace: Pojęcie kary kryminalnej i jej kulturowo historyczne uzasadnienie; Teorie kary i ich klasyfikacja (w kręgu naukowego dylematu kary odwetowej i celowej); Utylitaryzm karania i jego krytyka z pozycji neoklasycyzmu, [w:] System Prawa Karnego, t. 5. Nauka o karze. Sądowy wymiar kary, Warszawa 2015, s. 12 n., s. 36 n., s. 62 n.; J. Giezek, Okoliczności wptywające na sędziowski wymiar kary, Wrocław 1989; W. Świda, B. Wróblewski, Sędziowski wymiar kary w RP, Wilno 1939.

4 Zob. J. Makarewicz, Kodeks karny. Komentarz, Lwów 1938, s. 206. Bliżej o znaczeniu tych okoliczności dla wymiaru kary w praktyce powojennej zob. M. Siewierski, Kodeks karny i prawo o wykroczeniach. Komentarz, Warszawa 1965, s. 98 n.

5 Zob. w tej kwestii G. Szczygieł, Nadzwyczajny wymiar kary w kodeksie karnym z 1932 r., [w:] Kodeks karny z 1932 r., red. A. Grześkowiak, K. Wiak, Lublin 2015, s. 113 n. 
kary, wyrażona w art. 54 k.k. z 1932 r., oznacza prawo i obowiązek sędziego do wyboru kary i jej orzeczenia na podstawie wszystkich elementów o charakterze przedmiotowym i podmiotowym, które wymieniał także ten przepis. Nie oznaczało to jakiejś dowolności w decyzjach sędziego, lecz wskazywało sędziemu na potrzebę dokładnej oceny czynu i sprawcy ${ }^{6}$. Zasadzie swobodnej oceny sprzyjają ustawowe zagrożenia karą, które pozostawiają szerokie granice wyboru kary pomiędzy najniższą a najwyższą w ramach danego rodzaju kary, a także, w przewadze, możliwość wyboru rodzaju kary. W ustawowych ramkach zagrożenia karnego powinna mieścić się kara orzeczona w konkretnym przypadku (zwykły wymiar kary). Ustawowa zasada swobodnego wymiaru kary pozwala uniknąć schematyzmu przy jej orzekaniu, sędzia nie jest związany formalnymi warunkami i może dokonać jej wyboru stosownie do właściwości zdarzenia ${ }^{7}$. Kodeks karny nakładał na sędziego jedynie obowiązek wszechstronnego zbadania okoliczności indywidualnych danego przypadku i właściwości sprawcy ${ }^{8}$. Zasada swobodnego uznania sędziowskiego umożliwia i nakazuje zarazem indywidualizację przy orzekaniu kary z uwzględnieniem wszystkich wchodzących w rachubę okoliczności. W Uzasadnieniu projektu kodeksu karnego podkreśla się w sposób prosty i jednoznaczny, że kodeks przy ocenie poszczególnych przypadków nie wprowadza dla sędziego żadnych skrępowań. Sąd nie ma obowiązku przytaczania w wyroku i omawiania okoliczności łagodzących lub obciążających.

Jedyny obowiązek [...] to obowiązek wszechstronnego zbadania okoliczności indywidualnych danego wypadku i właściwości sprawcy. Z zestawienia tych okoliczności [...] wynika, że chodzi [...] o ocenę materiału faktycznego, któryby pozwolił odpowiedzieć na pytanie, czy i w jakim stopniu sprawca przestępstwa jest dla społeczeństwa niebezpieczny, a co za tym idzie, jakie należy zastosować środki, ażeby: 1) ochronić społeczeństwo przed tym niebezpieczeństwem, 2) przystosować sprawcę do warunków normalnego życia społecznego. Sędzia ma ten cel przed sobą ${ }^{9}$.

Zasada swobodnej oceny sędziowskiej w konkretnej sprawie służy tym samym indywidualizacji wymiaru kary, co było wyraźnym dążeniem szkoły socjologicznej w prawie karnym. Zasadę tę (druga spośród wymienionych) zawierał art. 55 kodeksu karnego. Przepis stanowił, że szczególne okoliczności wpływające na wymiar kary uwzględnia się tylko co do tej osoby której dotyczą. Zalecenie proste, zrozumiałe i ważne zarazem. Dotyczy wszelkich przypadków współdziałania przestępnego, a więc przypadków przestępstw, w których współdziałają co najmniej dwie osoby, np. jako współsprawcy albo w układzie podżegacz-pomocnik i sprawca sensu stricto. Wniosek jest taki, że to, co obciąża jednego ze współ-

6 Zob. J. Makarewicz, Kodeks karny..., s. 40, 205; zob. też W. Makowski, Kodeks karny. Komentarz, Warszawa 1937, s. 198 n.

7 W. Makowski, Kodeks karny..., s. 199

8 Ibidem, s. 200.

9 „Komisja kodyfikacyjna RP. Sekcja prawa karnego”, t. V, z. 3, s. 65-66. 
działających pod względem wymiaru kary, dotyczy tylko jego i nie może być rozciągalne na drugiego ze współdziałających. Chodzić tu może o każdą okoliczność, która wpływa na wymiar kary — zarówno przedmiotową, jak i podmiotową. Okoliczności te muszą być uwzględniane oddzielnie w stosunku do każdego ze sprawców. Zasada indywidualizacji kary (wymiaru kary), wyrażona w art. 55, jak przyjmowano w literaturze, stanowiła niejako uzupełnienie zasady indywidualizacji odpowiedzialności sformułowanej w art. 16 kodeksu $^{10}$. Stanowił on, że okoliczności wpływające na karalność czynu uwzględnia się tylko co do tej osoby, której dotyczą. Wskazywano, że takie okoliczności, jak wiek (brak pełnoletności karnej), recydywa, choroba umysłowa, pobudki czynu stwarzają dla każdego z działających inne warunki odpowiedzialności, co oznacza indywidualizację odpowiedzialności na podstawie osobistych stosunków uczestnika. Przy czym sformułowanie „okoliczności wpływające na karalność czynu” oznacza każdy rodzaj wpływu — zwiększenie karalności, zmniejszenie, a nawet całkowite jej uchylenie $^{11}$. Zasada trzecia spośród wymienionych nakazuje uwzględnianie przy wymiarze grzywny stosunków majątkowych sprawcy (art. 56). Ramy zagrożenia karnego, tak jak w przypadku innych kar, pozwalają na wybór kary w odpowiedniej wysokości. Oznacza to jej indywidualizację i jednocześnie stanowi podejście racjonalne, gdyż wymiar kary grzywny powinien być dostosowany do sytuacji ekonomicznej sprawcy. Nie jest to jedyne kryterium dla wymiaru tej kary, lecz jest to przesłanka o tyle racjonalna, że kara grzywny jest realna i zarazem odpowiednio dolegliwa. Obok tego podkreślano w literaturze i ten aspekt wymiaru grzywny, że nie powinna ona być przywilejem dla bogatych ${ }^{12}$. Zasada czwarta wskazuje na pierwszeństwo kary wolnościowej przed pozbawieniem wolności (art. 57 § 1). Jest to naturalnie również ważna zasada. Ustawa poleca, aby wymierzenie kary pozbawienia wolności następowało tylko wówczas, gdy wskazanie na karę grzywny nie byłoby celowe. Podkreślano w literaturze, że niecelowość skazania na grzywnę trzeba rozpatrywać z punktu widzenia interesu społecznego, któremu ma służyć represja karna. Niecelowość zachodziłaby wówczas, gdy skazany nie będzie miał możliwości uiszczenia grzywny, lecz także gdy nie odczułby on z uwagi na swoją zamożność dolegliwości z tego powodu ${ }^{13}$. Przepis stanowił o karze pozbawienia wolności, co oznaczało, że chodzi zarówno o więzienie, jak i o areszt (te dwie formy pozbawienia wolności znał kodeks karny z 1932 r.). Artykuł 57 ustanowił też regułę, że przy zagrożeniach alternatywnych — więzienie lub areszt — ten ostatni środek, jako łagodniejsza forma pozbawienia wolności, nie powinien być stosowany, jeżeli sprawca popełnił przestępstwo z niskich pobudek (§ 1). Ostatnia,

10 W. Makowski, Kodeks karny..., s. 204.

11 Ibidem, s. 79-80; bliżej o znaczeniu indywidualizacji wymiaru kary w opinii A. Mogilnickiego zob. M. Wąsowicz, Nurt socjologiczny w polskiej myśli prawniczej, Warszawa 1989, s. 191.

12 W. Makowski, Kodeks karny..., s. 205.

13 Ibidem, s. 206-207. 
piąta, zasada spośród dających się wyprowadzić z przepisów kodeksu o wymiarze kary dotyczy zaliczenia na poczet kary pozbawienia wolności okresu tymczasowego aresztowania (art. 58). Sąd został upoważniony do zaliczenia tymczasowego aresztowania w całości lub w części według swojej oceny danego przypadku. W Uzasadnieniu Komisji Kodyfikacyjnej podkreślono, że rozwiązanie to mieści się w ramach zasady swobodnego uznania ${ }^{14}$. Sąd miał prawo zaliczyć okres tymczasowego aresztowania w całości lub w części, lecz nie obowiązek.

Zasady wymiaru kary, wynikające z art. 54-58 k.k., dotyczyły kwestii podstawowych w kręgu zagadnień wymiaru kary. Zostały ujęte dość syntetycznie, były jednak ważne, a wynikające $\mathrm{z}$ nich wnioski praktyczne należy uznać za istotne dla praktyki wymiaru sprawiedliwości. Założenia te odpowiadały filozofii prewencji indywidualnej ${ }^{15}$. W odpowiednim stopniu odnosiły się również do wykroczeń (art. 2 Prawa o wykroczeniach).

Kodeks karny z 1969 r. przejął wszystkie dotychczasowe założenia dotyczące zasad wymiaru kary i odpowiednio je wzbogacił. Rozdział poświęcony tym zagadnieniom nosi dotychczasowy tytuł — „Wymiar kary” (art. 50-59). Przepisy tego rozdziału określały zasady ogólne wymiaru kary, zalecenia szczególne dotyczące wymiaru kary niektórym sprawcom (młodociani, recydywiści) oraz reguły odnoszące się do nadzwyczajnego wymiaru kary, tj. nadzwyczajne złagodzenie kary (art. 57), nadzwyczajne zaostrzenie kary sprawcom przestępstw o charakterze chuligańskim (art. 59), a także zaostrzenie kary orzekanej za przestępstwo ciągłe (art. 58). Natomiast nadzwyczajne zaostrzenie kary dotyczące recydywistów według ustawowych warunków zostało uregulowane w rozdziale odrębnym — „Powrót do przestępstwa” (art. 60) ${ }^{16}$. Jako ogólne zasady wymiaru kary wskazywano na podstawie rozwiązań przepisów tego kodeksu na: 1) zasadę oznaczoności wyroku, 2) zasadę swobodnego uznania sądu, 3) zasadę indywidualizacji kary. Nadto, art. $50 \mathrm{w} \S 1$ formułował trzy tzw. ogólne dyrektywy wymiaru kary: 1) współmierność kary do stopnia społecznego niebezpieczeństwa czynu, 2) społeczne oddziaływanie wymierzonej kary, 3) cele zapobiegawcze i wychowawcze, które kara ma osiągnąć w stosunku do skazanego ${ }^{17}$. Zasady swobodnej oceny sądowej oraz indywidualizacji wymiaru kary stanowią powtórzenie myśli zawartych w tychże zasadach sformułowanych w kodeksie z 1932 r. Ich istota się nie

14 „Komisja Kodyfikacyjna RP”, t. V, z. 3, s. 67.

15 Zob. K. Buchała, System sadowego wymiaru kary w projekcie kodeksu karnego, [w:] Problemy kodyfikacji prawa karnego. Księga ku czci Profesora Mariana Cieślaka, Kraków 1993, s. 131; por. M. Bojarski, J. Giezek, Z. Sienkiewicz, Polskie prawo karne materialne. Część ogólna i szczególna, red. M.Bojarski, wyd. V, Warszawa 2012, s. 390 n., s. 392.

${ }^{16}$ Pełną analizę problemów związanych z powrotem do przestępstwa, rozwiązań prawnych ulegających zmianie oraz praktyki sądowej przedstawił T. Szymanowski w pracy Recydywa w Polsce. Zagadnienia prawa karnego, kryminologii i polityki kryminalnej, Warszawa 2009.

17 Zob. I. Andrejew, W. Świda, W. Wolter, Kodeks karny z komentarzem, Warszawa 1973, s. $227 \mathrm{n}$. 
zmienia. Zasada swobodnego uznania sędziowskiego zawarta została w art. 50 § 1 zdanie 1, zasada indywidualizacji wymiaru kary - w art. 53. Zasada proporcjonalności grzywny do stosunków majątkowych sprawcy została wyrażona w art. 50 § 3. Artykuł 50 k.k. z 1969 r. nawiązywał zatem w istotnym zakresie do art. 54 k.k. z 1932 r. Nowe elementy, które się tutaj pojawiły, to kwestia tzw. ogólnych dyrektyw wymiaru kary, które trzeba rozumieć jako pewne zalecenia kierunkowe skierowane do sędziego, których nie nazywa się zasadami wymiaru kary, lecz z których wynikają również odpowiednie wskazania co do tego, czym ma się kierować sędzia przy orzekaniu kary ${ }^{18}$. Zasada swobodnej oceny sędziowskiej w swej istocie pozostaje niezmieniona, zasada indywidualizacji kary — również. Można je uznać za elementy stabilne w rozwiązaniach obu kodeksów w kwestii wymiaru kary, jako wyrażające wartość stałą. Zasada współmierności grzywny do stanu majątkowego sprawcy przy orzekaniu tej kary jest również elementem stałym w rozwiązaniach obu tych aktów prawnych, przy czym została odpowiednio rozwinięta. Przy wymierzaniu kary grzywny, w myśl $\S 3$ art. 50, sąd powinien uwzględniać stosunki majątkowe i dochody sprawcy, a także korzyść, którą sprawca osiągnął lub zamierzał osiągnąć z przestępstwa ${ }^{19}$. Należy więc przyjąć, że te trzy zasady wymiaru kary zostały jako słuszne powtórzone w kodeksie drugim niemal dosłownie. Natomiast wspomniane ogólne dyrektywy wymiaru kary nie są nazywane zasadami wymiaru kary, lecz przecież można z ich ustawowych sformułowań wyprowadzić odpowiednie wnioski — ważne dla wymiaru kary. Rozważając różnicę pomiędzy zasadami wymiaru kary a owymi dyrektywami, wolno przyjąć, że ogólne dyrektywy stanowią pewne wskazówki - jakby zalecenia kierunkowe co do tego, czym powinien kierować się sędzia przy wymiarze kary. Dyrektywy bywają określane jako technicznoprawne środki ograniczania luzu decyzyjnego w pracy sędziego ${ }^{20}$. Różnice pomiędzy zasadami wymiaru kary a dyrektywami wymiaru kary były dotychczas już przedmiotem szczegółowych rozważań. Wskazywano, że zasady wymiaru kary to reguły o charakterze normatywnym, rozstrzygające kwestie natury ogólnej dotyczące wymiaru kary, natomiast dyrektywy wymiaru kar (i środków karnych) to ustawowe wskazania kierunkowe ukierunkowujące sąd $\mathrm{w}$ tej kwestii ${ }^{21}$. Niekiedy używa się zamiennie

18 Zob. L. Gardocki, Prawo karne, wyd. 17, Warszawa 2012, s. 187 n.; A. Marek, Prawo karne, wyd. III, Warszawa 2011, s. 333 n., s. 338 n.; W. Wróbel, A. Zoll, Polskie prawo karne, część ogólna, Kraków 2010, s. 495 n.

19 Zob. bliżej w kwestii tej zasady I. Andrejew, W. Świda, W. Wolter, op. cit., s. 231.

20 J. Giezek [w:] Kodeks karny część ogólna. Komentarz, red. J. Giezek, Warszawa 2012, s. 382; por. O. Sitarz [w:] Prawo karne część ogólna, szczególna i wojskowa, red. T. Dukiet-Nagórska, Warszawa 2016, s. 293.

21 V. Konarska-Wrzosek, Dyrektywy wyboru kary w polskim ustawodawstwie karnym, Toruń 2002, s. 50, 73; zob. przedstawiona tam szersza charakterystyka zasad i dyrektyw wymiaru kary; zob. też J. Zgoliński, Kodeks karny. Komentarz, Warszawa 2016, s. 345 n.; por. M. Bojarski, J. Giezek, Z. Sienkiewicz, Prawo karne materialne. Część ogólna i szczególna, red. M. Bojarski, wyd. V, Warszawa 2012, s. 390 n., s. 394. 
określeń „zasady” i „dyrektywy”, np. w kwestii zasady humanitaryzmu, preferencji środków wolnościowych. Inna sprawa, czy można je wprost zaliczyć do zasad wymiaru kary. Zasady mają wprost moc wiążącą dla sędziego i dla pracy sądu. Do grupy zasad dotychczasowych kodeks z 1969 r. dodał jeszcze zasadę oznaczoności wyroku, wskazując, że sąd wymierza karę „w granicach przewidzianych w ustawie". Może przy redagowaniu art. 54 k.k. z 1932 r. uznano, że jest to oczywiste i wobec tego nie są konieczne odpowiednie sformułowania słowne co do tego, lecz trudno przeczyć trafności sformułowania tej zasady w przepisie dotyczącym wymiaru kary, chociaż z pewnością nie ulegało wątpliwości, że sąd może wymierzać karę tylko w ramach ustawowo zakreślonych. Jednak wzbogacenie zasad wymiaru kary, obok zasady swobodnego sędziowskiego uznania, zasady indywidualizacji kary i zasady adekwatności grzywny do stosunków majątkowych sprawcy, zasługuje na aprobatę. W kwestii wspomnianych ogólnych dyrektyw kary trzeba powiedzieć, że zawierają one ważne wskazówki co do kryteriów wymiaru kary. O niektórych można też powiedzieć, że stają się dalszymi zasadami tego wymiaru. Tak więc ustawowe polecenie oceny stopnia społecznego niebezpieczeństwa czynu przy orzekaniu kary trzeba również uznać za ważną zasadę wymiaru kary (zasada stopnia społecznej szkodliwości czynu). Miejsca na ocenę zachowania człowieka $\mathrm{z}$ tego punktu widzenia jest tu wiele, ocena czynu pod tym względem jest konieczna i niewątpliwie ma swoje znaczenie przy kształtowaniu wymiaru kary. Wielofunkcyjność tego określenia jest wiadoma, stopień społecznego niebezpieczeństwa (społecznej szkodliwości) czynu, obok ważnej okoliczności, dla wymiaru kary stanowił i stanowi warunek bytu przestępstwa według art. $26 \S 1$ k.k. z 1969 r. i art. 1 § 2 k.k. z 1997 r. (ma być ona wyższa niż znikoma) ${ }^{22}$. W ujęciu art. 50 § 1 k.k. z 1969 r. stopień społecznego niebezpieczeństwa czynu staje się dyrektywą — zasadą o charakterze sprawiedliwościowym, jakiś element odpłaty tu występuje. Potrzeba zadośćuczynienia społecznemu poczuciu sprawiedliwości została w ten sposób wyraźnie podkreślona. Natomiast dyrektywa wskazująca na społeczne oddziaływanie wymierzonej kary ma charakter ogólnoprewencyjny i nie jest łatwa do konkretyzacji związanych z nią celów. Bardziej konkretne i praktyczne znaczenie ma dyrektywa określona jako cele zapobiegawcze i wychowawcze orzeczonej kary. Jest to sprawa prewencji indywidualnej i ten akcent wyraźnie koresponduje z nastawieniem rozwiązań kodeksu karnego z 1932 r. właśnie na oddziaływanie indywidualnoprewencyjne ${ }^{23}$. Nie jest moim zamierzeniem bliższe rozważanie znaczenia, ogólnie pozytywnego, tych dyrektyw (zwłaszcza 1 i 3), zostały one już gruntownie opracowane i przedsta-

22 Zob. np. T. Bojarski, Funkcje pojęcia społecznej szkodliwości czynu, [w:] Wspótzależność materialnego i procesowego prawa karnego, red. Z. Ćwiąkalski, G. Artymiak, Warszawa 2009, s. 19 n.; idem, Znikomy stopień społecznej szkodliwości czynu — problemy kryteriów oceny, [w:] Aktualne problemy prawa karnego. Ksiega Pamiątkowa z okazji Jubileuszu 70. urodzin Profesora Andrzeja J. Szwarca, red. Ł. Pohl, Poznań 2009, s. 59.

23 Por. M. Bojarski, J. Giezek, Z. Sienkiewicz, op. cit., s. 393. 
wione przez wielu autorów oraz w opracowaniach zespołowych ${ }^{24}$, co nie przeczy celowości podejmowania dalszych rozważań na ten temat - niezależnie od tego, czy zaliczymy je wprost do zasad wymiaru kary, czy też nie, muszą one być uznane za ważne wskazania polskiego ustawodawcy w przedmiocie kryteriów wymiaru kary. Wskazują na cele orzeczonej kary, które chce się osiągnąć i które muszą być rozważone przez sędziego przy orzekaniu kary wobec konkretnego sprawcy w każdej sprawie. Natomiast wskazania szczegółowe przepis art. 50 (podobnie jak art. 54 kodeksu z 1932 r.), wyrażał w $\S 2$ bardziej rozbudowanym niż dawny art. 54. Dochodzimy więc do wniosku, że ważne zasady wymiaru kary, przyjęte w kodeksie z 1932 r. — zasada swobodnej oceny sądu, zasada indywidualizacji kary, zasada adekwatności kary grzywny do sytuacji majątkowej sprawcy — zostały wzbogacone w tym kodeksie o zasadę oznaczoności wyroku oraz o trzy ogólne dyrektywy wymiaru kary, wzmacniające te zasady. Zawierają one zalecenia kierunkowe co do wymiaru kary i nawiązują do koncepcji wielości celów kary (cel wychowawczy, poprawczy, odstraszający, eliminujący), co lokuje polskie rozwiązania ustawowe w grupie mieszanych teorii kary. Zasada priorytetu kary wolnościowej również znalazła potwierdzenie w kodeksie z 1969 r., lecz w innym ujęciu — w postaci zamiany rodzaju kary (art. 54 § 1). Przepis ten upoważniał sąd do rezygnacji, w pewnych przypadkach, z kary pozbawienia wolności i zastąpienia jej karą ograniczenia wolności lub grzywną. Chodziło o przypadki, gdy ustawowe zagrożenia karą pozbawienia wolności (tylko tą karą) nie było w dolnej granicy wyższe niż 3 miesiące, a wymierzona za nie kara pozbawienia wolności nie byłaby surowsza od 6 miesięcy pozbawienia wolności. Również zasada zaliczania tymczasowego aresztowania na poczet orzeczonej kary została utrzymana. Według przepisów tego kodeksu stała się obowiązkiem sądu i odnosiła się także do kary ograniczenia wolności i kary grzywny przy zastosowaniu odpowiednich przeliczników (art. $83 \S 2$ i $\S 3)^{25}$. Istotne są tu również zalecenia szczegółowe w kwestii wymiaru kary, dotyczące niektórych sprawców, tj. wymiaru kary mło-

${ }^{24}$ Dyrektywy wymiaru kary, red. J. Majewski, Warszawa 2014; K. Buchała, Dyrektywy sqdowego wymiaru kary, Warszawa 1989, idem, Założenia modelu sankcji i ich orzekania wedtug polskiego projektu kodeksu karnego, [w:] Problemy reformy prawa karnego, red. T. Bojarski, E. Skrętowicz, Lublin 1993, s. 25 n.; zob. też T. Bojarski, Możliwe praktyczne znaczenie ogólnych dyrektyw wymiaru kary dla polityki karnej, [w:] Zagadnienia współczesnej polityki karnej, red. T. Dukiet-Nagórska, Bielsko-Biała 2006, s. 44 n.; idem, Problemy wymiaru kary w świetle nowego kodeksu karnego, [w:] Polska lat dziewięćdziesiatych. Przemiany państwa i prawa, t. 2, red. L. Antonowicz et al., Lublin 1998, s. 279 n.; por. T. Kaczmarek, Ogólne dyrektywy wymiaru kary jako problem kodyfikacyjny, [w:] Problemy reformy prawa..., s. 47 n.

${ }^{25}$ Zob. bliżej W. Świda [w:] I. Andrejew, W. Świda, W. Wolter, op. cit., s. 322 n. Kwestia ta została uregulowana w rozdziale poświęconym zasadom wykonywania kary. Było to rozwiązanie trafne, ustawodawca, wypowiadając się co do kar, ich rodzajów i granic, nie powinien pomijać w zupełności aspektu wykonawczego. Tak nastąpiło to w przepisach kodeksu z 1997 r. Zagadnienia wykonawcze zostały przeniesione do kodeksu karnego wykonawczego, którego rola powinna być raczej techniczna. 
docianemu (art. 51) i wymiaru kary sprawcy uprzednio karanemu (art. 52). Są to ważne postanowienia, wobec młodocianego sąd powinien kierować się przede wszystkim tym, aby skazanego wychować, nauczyć zawodu i wdrożyć do przestrzegania porządku prawnego. Oznacza to priorytet wychowawczego celu kary, co sprzeciwia się orzekaniu kary pozbawienia wolności, a ogólnie - nastawieniu represyjnemu. Natomiast uprzednie skazanie sprawcy za przestępstwo umyślne lub za podobne przestępstwo nieumyślne sąd powinien traktować jako okoliczność wpływającą na zaostrzenie kary i co do zasady - sprzeciwiającą się orzekaniu kary łagodniejszego rodzaju przy zagrożeniach alternatywnych (art. 52). Stosownie do przyjętego na wstępie założenia pomijamy tu kwestie nadzwyczajnego wymiaru kary, tj. nadzwyczajnego złagodzenia (art. 57) i nadzwyczajnego zaostrzenia. Trzeba jednak podkreślić, że w przepisach rozdziału „Wymiar kary” znalazły się dwie nowe zasady - dotyczące wymiaru kary za przestępstwo ciągłe i za przestępstwo o charakterze chuligańskim. Nie analizując bliżej tych ważnych konstrukcji, należy tylko zwrócić uwagę na powiększenie podstaw nadzwyczajnego zaostrzenia kary w stosunku do sprawcy przestępstwa ciągłego i przestępstwa o charakterze chuligańskim. Na zakończenie charakterystyki postanowień kodeksu karnego z 1969 r. w kwestii wymiaru kary trzeba podkreślić, że kodeks ten przejął z kodeksu poprzedniego (1932 r.) dotychczasowe zasady wymiaru kary, wzbogacił je oraz uzupełnił o ogólne dyrektywy wymiaru kary. Można uznać, że jest to właściwy kierunek rozwiązań prawnych na tym odcinku. Wyraźne jest dążenie do jeszcze szerszego niż w kodeksie karnym z 1932 r. rozwinięcia zasad i odpowiednich wskazań kierunkowych co do wymiaru kary. Wynikająca z nowych postanowień kodeksu zwiększona dyrektywność nie powinna być oceniana jako formalizowanie reguł wymiaru kary, krępujące sędziego. Odpowiednio zbliżone rozwiązania w tym zakresie przejął kodeks wykroczeń z 1971 r., lecz już w rozwiązaniach samodzielnych, a nie przez odesłania do kodeksu karnego, jak w ustawodawstwie z $1932 \mathrm{r}$.

Tak więc w przepisach kodeksu z 1932 r. i 1969 r. ukształtowały się następujące ważne zasady wymiaru kary: 1) zasada swobodnego sądowego uznania, 2) zasada indywidualizacji kary, 3) zasada zależności kary grzywny od sytuacji majątkowej sprawcy, 4) zasada preferencji kary wolnościowej, 5) zasada zaliczania aresztu tymczasowego na poczet orzeczonej kary (w k.k. 1969 nie tylko pozbawienia wolności), 6) zasada oznaczoności wyroku (oznaczoności kary). Oprócz tych zasad wprowadzone zostały do ustawy (k.k. z 1969 r.) tzw. dyrektywy ogólne: 1) dyrektywa stopnia społecznego niebezpieczeństwa czynu (obecnie - społecznej szkodliwości czynu), 2) dyrektywa prewencji szczególnej, 3) dyrektywa prewencji ogólnej. Trzeci polski kodeks karny (z 1997 r.) utrzymał wszystkie te zasady i dyrektywy ogólne, odpowiednio je wzbogacając. Zagadnienia te zostały uregulowane w rozdziale „Zasady wymiaru kar i środków karnych”. Zasada swobodnego uznania sądowego (swobody sędziowskiej) oraz oznaczoności kar znala- 
zły uregulowanie w art. 50 § 1 zdanie 1. Podkreśla się w literaturze konstytucyjne umocowanie zasady swobodnego uznania sędziowskiego ${ }^{26}$. Zasada indywidualizacji wymiaru kary zawiera się w art. 55. Zasada zależności grzywny od stosunków majątkowych sprawcy została wyrażona w art. $43 \S 3$ k.k. (przepis określający karę grzywny znajdujący się w rozdziale „Kary”). Zasada preferencji kary wolnościowej została zaakcentowania w art. 58 niejako dwukrotnie - w $\S 1$ tego przepisu zastrzega się, że jeżeli ustawa przewiduje możliwość wyboru kary, sąd orzeka karę pozbawienia wolności bez warunkowego zawieszenia jej wykonania tylko wtedy, gdy inna kara lub środek karny nie może spełnić celów kary. W § 3 tego przepisu wprowadzono rozwiązanie pozwalające na zamianę rodzaju kary, tj. orzeczenie zamiast kary pozbawienia wolności, grzywny albo kary ograniczenia wolności ${ }^{27}$. Zasada zaliczania tymczasowego aresztowania na poczet orzeczonej kary została sformułowana w art. 63. Na podkreślenie zasługuje nowa formalnie zasada sformułowana w art. 3 k.k. — zasada humanitaryzmu. Przepis stanowi, że kary i inne środki przewidziane w kodeksie stosuje się z uwzględnieniem zasad humanitaryzmu, w szczególności z poszanowaniem godności człowieka. Ustawowe określenie tej zasady należy uznać za istotne dla ogólnego obrazu polityki karnej w Polsce po 1990 r. ${ }^{28}$ Należy uznać, że jest to ważny komplet zasady wymiaru kary. Istotne w tym zakresie jest również zachowanie ogólnych dyrektyw wymiar kary. Przy czym nastąpiły tu korzystne zmiany — pojęcie społecznego niebezpieczeństwa czynu zostało zastąpione określeniem ,społeczna szkodliwość czynu". Natomiast dyrektywa prewencji ogólnej została przeredagowana w kierunku bliższym tzw. pozytywnej prewencji generalnej. Gruntowne, najnowsze, opracowanie tej dyrektywy przedstawia książka A. Kani poświęcona tym zagadnieniom $^{29}$. Do zespołu dotychczasowych dyrektyw ogólnych dodano jeszcze

26 Zob. M. Bojarski, J. Giezek, Z. Sienkiewicz, op. cit., s. 366.

27 Już w czasie obowiązywania kodeksu z 1997 r. dodano przepisy art. 59a i 60a, które jeszcze poszerzyły możliwość eliminowania kary pozbawienia wolności, w warunkach określonych w tych przepisach. Mogło mieć miejsce umorzenie postępowania w odniesieniu do występków nawet zagrożonych karą pozbawienia wolności do lat 5 (art. 59a). Mogło mieć również miejsce odstąpienie od wymierzenia kary w warunkach określonych w art. 60a. Można uznać te rozwiązania liberalizujące kwestie odpowiedzialności karnej sprawców, nie tylko drobnych, za daleko idące, i w związku z tym należy uznać za trafne uchylenie tych przepisów przez ustawę z 11 marca 2016 r., Dz.U. z 2016 r. poz. 437. Pozostaje jeszcze sprawa art. 75a, który to przepis pozwala, w przypadkach gdy zachodzą podstawy (jednoznaczne) odwołania warunkowego zawieszenia wykonania kary, zastąpić tę karę karą łagodniejszą, nie zarządzając wykonania kary pozbawienia wolności. Przepis ten został dodany przez ustawę z 20 lutego 2015 r., Dz.U. z 2015 r. poz. 396. Rozwiązanie w moim przekonaniu zdumiewające - zob. bliżej T. Bojarski, Uwagi o środkach zwiąanych z okresem próby na tle nowelizacji kodeksu karnego, „Studia Ekonomiczne, Prawne i Administracyjne” 2016, nr 1, s. 4 n.

28 Zob. bliżej A. Zoll [w:] Kodeks karny. Część ogólna, t. I, red. A.Zoll, wyd. 4, Warszawa 2012, s. 100 n.

29 A. Kania, Prewencja ogólna jako dyrektywa sadowego wymiaru kary. Rozważania na tle kodeksu karnego, „Acta Lebusana” 1, Zielona Góra 2016. 
dyrektywę winy - kara nie powinna przekraczać stopnia winy ${ }^{30}$. W ten sposób zespół zasad i dyrektyw wymiaru kary jest — wolno powiedzieć — pełny, zawiera ważne zalecenia dla sędziego (sądu), którymi powinien on kierować się przy wyborze rodzaju kary i jej wymiarze. Zaznaczyć też trzeba, że zostały zachowane zalecenia kierunkowe w kwestii karania nieletnich i młodocianych (art. 54), akcentujące cel wychowawczy kary. Inna, ważna w kontekście tych zagadnień, zasada normatywna nakazuje, aby przy zbiegu podstaw nadzwyczajnego złagodzenia albo obostrzenia nadzwyczajne złagodzenie lub obostrzenie mogło nastąpić tylko raz. Trzeba także zaznaczyć, że kodeks trzeci zrezygnował ze sformułowania przesłanek nadzwyczajnego zaostrzenia kary wobec sprawcy przestępstwa ciągłego oraz sprawcy przestępstwa o charakterze chuligańskim. Zmiana w tej ostatniej sprawie nastąpiła dopiero w czasie obowiązywania kodeksu karnego. Artykuł 57a wprowadził ponownie nadzwyczajne zaostrzenie kary wobec sprawcy przestępstwa o charakterze chuligańskim (ustawa z 16 listopada 2006 r., Dz.U. Nr 226, poz. 1648). W kodeksie trzecim w parze z tym szły odpowiednie złagodzenia kary pozbawienia wolności. Towarzyszyła im również tendencja do poszukiwania rozwiązań kompensacyjnych ${ }^{31}$.

Wolno więc w podsumowaniu nakreślonych uwag na temat zasad wymiaru kary w polskich kodeksach karnych z przekonaniem podkreślić, że kształtowanie tych zasad od 1932 r. i ich dalszy rozwój przebiegały prawidłowo. Wyraźna była dążność polskiego ustawodawcy przy uchwalaniu kolejnych kodeksów karnych do utrwalania i poszerzania zasad wymiaru kary, zgodnych z nowoczesnymi dążeniami do łagodzenia polityki karnej. W kodeksie trzecim w parze z tym szły odpowiednie złagodzenia dolnych granic kary.

\section{Remarks on the principles of imposing penalties in Polish criminal codes}

\section{Summary}

This paper covers issues related to the principles of imposing penalties. Apart from their considerable practical significance, these directives are closely related to the theory and philosophy of punishment. The purpose of these comments is a simple indication of the assumptions underlying the principles of imposing penalties, including the way of their evolution in Polish criminal law since 1932. The choice of theme is justified by the importance, the true wealth of problems that

$30 \mathrm{~W}$ opinii niektórych autorów przyjmuje się, że w art. 53 § 1 k.k. określone zostały dwie dyrektywy ogólne - dyrektywa prewencji indywidualnej i dyrektywa prewencji szczególnej zob. W. Wróbel [w:] Kodeks karny część ogólna, s. 733.

31 Zob. bliżej w tej kwestii Z. Sienkiewicz, O kompensacji w nowym kodeksie karnym, [w:] U progu nowych kodeksów karnych. Ksiega Jubileuszowa dedykowana Profesorowi Leonowi Tyszkiewiczowi, red. O. Górniok, Katowice 1999, s. 110 n. Podkreślić trzeba, że podstawowe założenia w kwestii zasad i dyrektyw wymiaru kary przyjęte w kodeksie karnym z 1997 r. znalazły swoje zastosowanie również w przepisach kodeksu karnego skarbowego z 1999 r. (art. 12). 
occur here and the theoretical but also research interests of Professor Tomasz Kaczmarek. The author wants to emphasize that the evolution of the principles of imposing penalties from the first statutory regulations runs properly. A clear tendency in the Polish legislature was consolidation and expansion of these directives, which remain compatible with the new less repressive criminal and sanctions policy. The Penal Code currently in force provided also appropriate lower limits of penalties.

Keywords: criminal justice, punishment, theories of punishment, principles of imposing penalties, purposes of punishment. 